\title{
KRITERIA SUNNAH TASYRI'IYAH YANG MESTI DIIKUTI
}

\author{
Kaizal Bay \\ Fakultas Ushuluddin UIN Sultan Syarif Kasim Riau \\ kaizal.bay@uin-suska.ac.id
}

\begin{abstract}
Abstrak
Ulama sepakat bahwa Sunnah dengan sanad yang shahih memfaedahkan qath'i dan kebenarannya adalah hujjah (dalil) bagi kaum muslimin. Maka ia dipandang sebagai sumber tasyri', dan sebagaimana halnya al-Qur'an wajib diikuti. Satu hal yang harus diyakini, pada umumnya Sunnah Rasul, baik yang berbentuk ucapan, perbuatan, dan ketetapannya mempunyai implikasi hukum yang mesti diikuti (Sunnah Tasyri'iyyah), dengan kriteria di antaranya seperti perbuatan Nabi Saw. dalam bentuk penyampaian risalah dan penjelasannya terhadap al-Qur'an tentang berbagai masalah yang masih bersifat umum dan mutlak. Beliau menjelaskan bentuk dan tata cara shalat, haji, dan lainya dalam kapasitasnya sebagai Rasul. Banyak ayat al-Qur'an yang memerintahkan untuk mengikuti Sunnah nabi Saw. itu dalam kehidupan. Adapun sebagian ulama menyepakati, ada sekian banyak Sunah yang tidak berimplikasi hukum yang tidak mesti diikuti (ghairu tasyri'iyyah), terutama yang berkaitan dengan beberapa persoalan keduniaan yang timbul dari hajat insani dalam kehidupan keseharian Nabi, seperti cara berpakaian, urusan pertanian dan lainnya, dan hukum mengikutinya hanya sebatas sunnah atau mubah. Istilah Sunnah ghairu tasyri'iyah masih diperdebatan (ada yang pro dan ada yang kontra) dan tidak dikenal pada masa salaf al-salih. Munculnya istilah Sunnah ghairu tasyri'iyah pada akhir abad 14 H, di antara pencetus Syekh Muhammad Syaltut.
\end{abstract}

Kata kunci: al-Qur'an, Sunnah, dan Tassyri'iyah

\section{Pendahuluan}

Sudah dimaklumi bahwa referensi pokok di dalam syari'at Islam adalah al-Qur'an dan Sunnah Rasul, sebagaimana firman Allah: "Kemudian, jika kamu berbeda pendapat tentang sesuatu, maka kembalikan kepada Allah (alQur'an) dan Rasul (Sunnahnya)" (QS. an-Nisa': 59). Di samping itu, Rasulullah Saw. juga bersabda: "Ketahuilah bahwa aku telah diberi alQur'an dan yang semisal dengannya (Sunnah)", (HR. Abu Daud). Jelaslah yang menyamai (semisal) al-Qur'an di sini adalah Sunnah yang merupakan pedoman untuk diamalkan dan ditaati sejajar dengan al-Qur'an. Adapun al-Qur'an itu terjaga karena disampaikan kepada kita secara mutawatir yang murupakan derajat tertinggi di dalam mengukuhkan sebuah berita. Sedangkan Sunnah Rasulullah Saw. merupakan penerang dan penjelas untuk al-Qur'an, pengkhusus perkaraperkara umum yang tercantum di dalam alQur'an, dan sekaligus pengecuali dan pengkait untuk perkara-perkara yang mutlak. ${ }^{1}$ Tidak

\footnotetext{
${ }^{1}$ Syeikh Muhammad Nashiruddin al-Albani, Berhujjah Dengan Hadits Ahad; dalam Masalah Akidah dan Hukum, Penterjemah Darwis, Lc, Cet. I (Jakarta: Darus Sunnah Press, 2008), 34-35; Lihat dan bandingkan Fatchur Rahman, Ikhtishar Mushthalahu'l Hadits, Cet. VII (Bandung: PT. Al-Ma'arif, 1991), 1-3.
} 
mungkin kita bisa memahami al-Qur'an dan apalagi mengamalkannya, kecuali dengan merujuk kepada Sunnah. Sehingga secara faktual Nabi Saw. adalah manifestasi al-Qur'an yang pragmatis. $^{2}$

Sunnah pada dasarnya berarti perilaku teladan dari seseorang tertentu. Dalam konteks jurisprudensi Islam, ia merujuk kepada model perilaku Rasul. Konsep Islam tentang Sunnah bersumber dari pada diutusnya Rasul, karena alQur'an memerintahkan kepada kaum Muslimin untuk mencontoh perilaku Rasul, dinyatakan sebagai teladan dan agung, maka perilaku Nabi Saw. lalu menjadi "ideal" bagi kaum Muslimin. AlQur'an meminta kepada Rasul untuk memutuskan persoalan-persoalan yang dihadapi kaum Muslimin dengan dasar wahyu. Otoritas pokok bagi legislasi Islam adalah al-Qur'an. Meskipun demikian, alQur'an juga menyatakan bahwa Rasulullah adalah penafsir ayat-ayat al-Qur'an. ${ }^{3}$ Lebih jauh, al-Qur'an menerangkan akan fungsi Rasul, yaitu mengumumkan wahyu kepada orang banyak, memberikan didikan moral kepada mereka serta mengajarkan Kitab Suci dan kearifan.

Tidak dapat disangkal, dalam kehidupan seorang muslim, al-Qur'an dan Sunnah merupakan dua sumber ajaran yang mengatur banyak hal dan harus dipedomani dalam hidup. Allah berfirman:

"Dan Kami turunkan al-Qur'an kepadamu supaya engkau menjelaskan kepada manusia apa-apa yang diturunkan kepada mereka, supaya mereka berpikir" (QS. an-Nahl: 44).

Al-Qur'an tidak hanya berisikan persoalan akidah dan ibadah, tetapi mencakup berbagai persoalan etika, moral, hukum dan sistem

\footnotetext{
${ }^{2}$ Aktualiksasi prinsip-prinsip dasar al-Qur' an yang bersifat teoretik, dioperasionalisasikan oleh Nabi Muhamma Saw. melalui peneladanan. Lihat Yusuf al-Qardhawi, Al-Qur'an dan al-Sunnah, Terj. Bahrudin Fanani (Jakarta: Rabbani Press, 1997), 61.

${ }^{3}$ Ahmad Hasan, Pintu Ijtihat Sebelum Tertutup

(Bandung: Pustaka, 1984), 44.
}

kehidupan lainnya. Ajarannya berlaku sepanjang masa dan bersifat universal untuk semua umat manusia. Ilmu pengetahuan modern membuktikan sekian banyak isyarat ilmiah dalam al-Qur'an, bahkan juga Sunnah dan sejalan dengan penemuan ilmu para ahli.

Meskipun al-Qur'an menyatakan dirinya telah "menjelaskan segala sesuatu", namun tidaklah berarti bahwa al-Qur'an tidak memerlukan penjelasan. Jumlah ayatnya yang terbatas (666 ayat) dan karakteristik bahasanya yang ringkas dan padat serta kandungannya yang bersifat umum, menuntut adanya penjelasan atau penafsiran. Otoritas tertinggi untuk itu, dimiliki oleh Rasulullah Saw. yang diwujudkan dalam bentuk ucapan, perbuatan dan ketatapan. Himpuanan ketiganya disebut "Sunnah atau Hadis". Dengan demikian, sebagai sumber ajaran Islam al-Qur'an dan Sunnah tidak dapat dipisahkan. Karena itu, jika al-Qur'an dipandang sebagai sesuah konstitusi (dustur) yang mengandung pokok-pokok ajaran Ketuhanan yang diperlukan untuk mengarahkan kehidupan manusia, maka sunnah merupakan rincian penjelasannya. Al-Qur'an sendiri menyatakan, selain bertugas menyampaikan kitab suci, maka Rasulullah Saw. diberi kewenangan untuk menjelaskan kitab tersebut (QS. an-Nahl: 44). Penjelaskan itu tidak pernah keliru, sebab dalam menjalankan tugas tersebut Rasulullah Saw. senantiasa berada dalam bimbingan wahyu (QS. an-Najm: 3-4).

Dengan kata lain, tanpa sunnah, banyak hal yang menyangkut ibadah dan mu'amalah dalam Islam yang tidak akan pernah diketahui. Dalam al-Qur'an ditemukan perintah shalat, tetapi tidak ditemukan penjelasan rinci mengenai bilangan rakaatnya, tata cara dan waktu mengerjakannya, serta jenis shalat yang diwajibkan dan dianjurkan, maka penjelasan semua itu ada dalam sunnah, dan Sunnah itulah yang memberi bentuk konkrit kepada ajaran alQur'an. Begitu pula kadar, jenis dan waktu pelaksanaan zakat serta tata cara pelaksaan haji 
dan lainnya, juga tidak ditemukan dalam alQur'an, tatapi hanya diterangkan secara global oleh al-Qur'an. ${ }^{4}$ Karena itu, banyak ulama memahami keduanya merupakan satu kesatuan yang tidak dapat dipisahkan, sehingga mengamalkan Sunnah berarti juga mengamalkan al-Qur'an. Firman Allah:

"Barang siapa taat kepada Rasul, maka sungguh dia telah taat kepada Allah, dan barang siapa yang berpaling, maka kami tidak mengutus engkau sebagai penjaga atas mereka" (QS. an-Nisa': 80).

Suatu hal yang perlu disadari, persoalan agama bukan hanya pada otentitas teks-teks keagamaan, tetapi pada pemahaman yang baik dan benar. Keaslian dan kemurnian teks al-Qur'an dan Sunnah sebagai sumber ajaran agama tidak diragukan lagi dan sejarah telah membuktikan. Tetapi khazanah intelektual Islam menyodorkan fakta sekian banyak perbedaan menyangkut pemahaman teks-teks tersebut. Sifat al-Qur'an yang dinyatakan banyak pakar sebagai hamalatu awjud mengandung kemungkinan ragam interpretasi. Semuanya dapat dibenarkan, selama

\footnotetext{
${ }^{4}$ Sebagai sumber utama hukum Islam, al-Qur'an memuat pokok-pokok permasalahan yang menyangkut kebutuhan umat manusia. Allah SWT. tidak melupakan sedikit pun hal-hal yang dibutuhkan manusia di dalam al-Qur'an (QS. an-An'am: 38). Al-Qur'an menjelaskan dasar-dasar hukum itu secara rinci dalam lapangan kepercayaan ('aqidah), tatapi dalam lapangan ibadah dan mu'amalah hanya diberikan petunjuk-petunjuk secara garis besar. Memang dalam Kitab Suci ini terdapat beberapa persoalan yang dijelaskan secara agak rinci, tetapi hal itu sangat terbatas seperti warisan, cara me-li'an, wanita-wanita yang dilarang dinikahi dan hukuman hudud, dan selainnya diungkapkan secara umum. Karena itu, keumuman al-Qur'an dalam menjelaskan hukum-hukumnya, tentu saja memerlukan penjelasan dan yang menjelaskan itu adalah Sunnah Nabi Saw. Lihat Muhammad Abu Zahrah, Ushul Fiqh (Kairo, Dar al-Fikr al-Araaby, 1958), 70-71; Lihat dan bandingkan, Alaiddin Koto, Ilmu Fiqh dan Ushul Fiqh, Cet.IV (Jakarta: PT.Raja Grafindo Persada, 2011), 66-67; Lihat juga, Muchlis M. Hanafi, "Pola interaksi dengan al-Qur'an dan Sunnah“, Makalah disampaikan pada Kuliah Umum Jurusan Tafsir Hadis UIN Sunan Kalijaga Yogyakarta, 2008, 2-3.
}

berpegang kepada prinsip-prinsip kebahasaan dan syari'at Islam.

Adapun yang lebih problematis lagi, ketika teks-teks itu berupa sunnah (Hadis), sebab dalam memahaminya diperlukan pengetahuan tentang latar belakang historisnya (asbab al-wurud) dan maksud (maqashid) di balik pesan-pesan Sunnah tersebut. Namun, satu hal yang harus diyakini, kebanyakan Sunnah Rasul, baik yang berbentuk ucapan, perbuatan dan ketetapan adalah mempunyai implikasi hukum yang harus diikuti (tasyri'iyah), karena dengan mengikutinya kita akan mendapat petunjuk (QS. al-A'raf: 158). Tetapi sebagian ulama, juga sepakat ada sekian banyak Sunnah yang tidak berimplikasi hukum dan tidak mesti di ikuti (ghairu tasyri'iyah), terutama yang berkaitan dengan berbagai persoalan keduniaan. Di antara ulama yang mengklasifikasikan Sunnah dalam bentuk di atas, ialah al-Qarafi (w.684 H), M. Rasyid Ridha, dan Mahmud Syaltut.

\section{Pengetian Sunnah}

Sunnah secara etimologis bermakna "jalan yang biasa dilalui atau suatu cara yang selalu dilakukan, tanpa mempermasalahkan apakah masalah tersebut baik atau buruk", juga berarti "Perilaku atau cara berperilaku yang dilakukan seorang, baik cara yang terpuji maupun tercela". Jadi ada sunnah yang baik dan ada pula sunnah yang buruk. Dalam pengertian inilah dipahami kata sunnah, dalam hadis shahih yang diriwayatkan oleh Muslim, yaitu:

"Barang siapa yang melakukan perilaku
(Sunnah) yang baik dalam Islam, maka ia akan
mendapat pahalanya dan pahala orang yang
menirunya dan sedikitpun tidak dikurangi, dan
barang siapa yang melakukan perilaku
(Sunnah) yang buruk dalam Islam, maka ia
akan mendapat dosanya dan dosa orangyang
menirunya dan sedikitpun tidak dikurangi".5

${ }^{5}$ Kata "Sunnah" yang dipergunakan oleh hadis tersebut adalah kata Sunnah dengan pengertian etimologis. Maksudnya, orang yang membuat kebiasaan yang baik, 
Secara terminologis, pengertian Sunnah dapat dilihat dari 3 (tiga) disiplin ilmu, yaitu:

1. Ahli Hadis, para ahli Hadis mengidentikkan Sunnah dengan Hadis yaitu segala sesuatu yang disandarkan kepada Nabi Muhammad Saw. baik perkataan, perbuatan maupun ketetapannya.

2. Ilmu Ushul Fiqh, menurut ulama ahli Ushul Fiqh bahwa Sunnah adalah segala yang diriwayatkan dari Nabi Saw. berupa perkataan, perbuatan dan ketetapannya yang berkaitan dengan "hukum".

3. Ilmu Fiqh, pengertian Sunnah menurut ahli Fiqh hampir sama dengan pengertian yang dikemukakan oleh para ahli Ushul Fiqh. Akan tetapi istilah Sunnah dalam Fiqh, juga dimaksudkan sebagai salah satu hukum taklifi, yang berarti suatu perbuatan yang akan mendapat pahala bila dikerjakan dan tidak berdosa bila ditinggalkan. ${ }^{6}$

maka ia mendapatkan pahala dari perbuatannya itu dan dari perbuatan orang yang mengikutinya. Sebaliknya, orang yang membuat kebiasaan yang buruk, maka ia akan mendapatkan dosa dari perbuatannya itu dan dari perbuatan orang yang mengikutinya hingga hari kiamat. Musthafa alSiba'i, Al-Sunnah wa Makanatuha fi al Tasyri', 1; Baca dan bandingkan, Yusuf Qardhawi, Sunnah dan Bid'ah, Cet. IV (Jakarta: Gema Insani, 2004), 9-10; lihat juga Satria Effendi \& M.Zein, Ushul Fiqh (Jakarta: Kencana, 2005), 112 .

${ }^{6}$ Kata "Sunnah" dalam pengertian terminologi Fuqaha' adalah salah satu hukum syari'at atau antonim dari kata (fardhu dan wajib). Ia bermakna sesuatu yang dianjurkan untuk dikerjakan, namun dengan perintah yang tidak pasti. Sehingga orang yang mengerjakannya akan mendapat pahala, dan orang yang yang tidak mengerjakannya tidak dosa kecuali orang itu menolaknya. Sedangkan menurut ahli Ushul Fiqh, Sunnah adalah apa yang diriwayatkan dari Nabi Saw. berupa ucapan, perbuatan dan persetujuannya. Ia dalam pandangan mereka adalah salah satu sumber dari berbagai sumber syari'at. Karena itu, ia bergandengan dengan al-Qur'an. Misalnya, ada redaksi ulama mengatakan tentang hukum sesuatu, "masalah ini telah ditetapkan hukumnya oleh al-Qur'an dan Sunnah". Sementara, ulama Hadis menambah definisi lain tentang Sunnah. Mereka mengatakan, Sunnah adalah apa yang di-nisbat-kan kepada Nabi Saw. berupa ucapan, perbuatan, persetujuan, atau deskripsi baik fisik maupun akhlak, atau juga sirah (biografi Rasul Saw.) Namun, ada juga makna Sunnah yang lain yang menjadi perhatian para ulama syari' at, yaitu Sunnah dengan
Sementara itu, Jumhur Ulama Hadis juga mengatian al-Sunah, al-Hadis, al-Khabar dan alAtsar sama saja, yaitu segala sesuatu yang disandarkan kepada Nabi Muhammad Saw. baik dalam bentuk ucapan, perbuatan maupun ketetapan. Pengertian didasarkan kepada pandangan mereka terhadap Nabi sebagai suri tauladan yang baik (uswatun hasanah) bagi manusia. ${ }^{7}$ Sedangkan ulama Ushul mengartikan Sunnah adalah sesuatu yang berasal dari Nabi Muhammad Saw. dalam bentuk ucapan, perbuatan dan persetujuan beliau yang berkaitan dengan hukum. Pengertian ini didasarkan kepada pandangan mereka yang menempatkan Nabi Saw. sebagai pembuat hukum. Sementara itu, ulama fiqh mengartikan sunnah sebagai salah satu bentuk hukum syara', dan apabila dikerjakan mendapat pahala dan bila ditinggalkan tidak disiksa.

Pada prinsipnya yang dimaksud dengan Sunnah adalah segala sesuatu yang dibangsakan kepada Nabi Saw. baik berupa perkataan, perbuatan maupun ketetapannya. Hanya saja ulama ushul fiqh, menambah pengertian tersebut dengan suatu kait, yaitu "yang berkaitan dengan hukum". Artinya, yang dimaksud sunnah dalam pandangan mereka adalah "segala sesuatu sesuatu yang dibangsakan kepada Nabi Saw. yang

pengertian antonim dari "bid'ah". Baca Yusuf Qardhawi, 12-13; Lihat dan bandingkan Rachmat Syafe'i, Ilmu Ushul Fiqh, Cet.I (Bandung: CV. Pustaka Setia, 1999), 59-60; Lihat pula, Duski Ibrahim, Metode Penetapan Hukum Islam: Membongkar Konsep al-Istiqra, Al-Ma'nawi AsySyatibi (Yogyakarta: Ar-Ruzz Media, 2008), 92-93; Baca juga, Sadiq Hasan Khan, Husul al-Ma'mul fi 'ilm al-Ushul (Kairo: Dar al-Fikr al-'Arabi, 1284 H), 44.

${ }^{7}$ Ta'rif hadis (sunnah) yang luas, dikemukakan sebagian muhaddisin, tidak hanya mencakup sesuatu yang di-marfu'kan kepada Nabi Saw. saja, tetapi juga perkataan, perbuatan dan taqrir yang disandarkan kepada kepada sahabat dan tabi'i-pun disebut hadis. Dengan demikian hadis (sunnah) menurut mereka adala meliputi segala berita yang marfu', mauquf (disandarkan kepada sahabat) dan maqthu' (disandarkan kepada tabi'iy). Muhammad Mahfudh atTarmusy, Manhaj Dzawin Nadhar (Kairo: Mathba'ah Sa'adah, t.th), 7; Lihat dan bandingkan Abuddin Nata, Metodologi Studi Islam, Cet. IX (Jakarta: PT. Raja Grafindo Persada, 2004), 73. 
berkaitan dengan hukum". Ulama ushul membahas pribadi dan perilaku Nabi Saw. sebagai peletak dasar hukum syara', yang dijadikan landasan para Mujtahid di zaman sesudah beliau. Di samping itu, mereka memandang beliau sebagai yang memberikan penjelasan tentang undang-undang kehidupan. Adapun ucapan, perbuatan dan taqrir yang dimaksud adalah segala yang berkaitan dengan penetapan hukum dan pengukuhannya.

Berdasarkan definisi di atas, maka yang tepat dan sesuai digunakan dalam tulisan ini adalah definisi yang dikemukakan oleh ulama ushul fiqh. Karena dalam tulisan ini akan dipaparkan tentang kriteria Sunnah Tasyri'iyah (berdaya hukum) yang mengikat untuk diikuti bagi umat manusia.

Sunnah menurut pengertian ahli ushul, bila dilihat dari segi materi dan esensinya terbagi kepada tiga macam, yaitu:

1. Sunnah Qauliyah, ialah perkataan yang pernah Nabi Saw. ucapkan dalam berbagai bidang, seperti bidang hukum, akhlak, 'aqidah dan lainnya. ${ }^{8}$ Contoh perkataan beliau yang mengandung hukum, dalam sabdanya: "Sesunguhnya segala amal perbuatan itu hanyalah menurut niatnya, dan sesungguhnya bagi seseorang itu hanyalah apa yang di niatkannya'(H.R. Muttafaqun 'alaihi). Adapun hukum yang terkandung dalam hadis Nabi tersebut, yaitu kewajiban niat dalam segala amal perbuatan, guna untuk mendapatkan pengakuan sah dari pada syara'.

2. Sunnah Fi'liyah, adalah segala tindakan Rasulullah Saw. sebagai Rasul. Misalnya tindakan beliau mengerjakan shalat lima waktu dengan menyempurnakan tata caranya, syaratnya dan rukun melaksanakannya. ${ }^{9}$

\footnotetext{
${ }^{8}$ Fatchur Rahman, 6-7; Baca dan bandingkan, Nazar Bakry, Fiqh dan Ushul Fiqh, Cet. IV (Jakarta: PT.Raja Grafindo Persada, 2003), 40-41.

${ }^{9}$ Muchtar Yahya dan Fatchurrahman, Dasar-dasar Pembinaan Hukum Fiqh Islami (Bandung: PT. Al-Ma'arif, Bandung, 1983), 39.
}

Demikian pula masalah yang berkaitan dengan ibadah haji, di mana dalam al-Qur'an hanya disebutkan kewajiban melakukan haji, tanpa ada penjelasan tata cara dengan rinci dan lainnya. Dengan kata lain, Sunnah fi'liyah, yaitu perbuatan Nabi Saw. yang merupakan perjelasan praktis terhadap peraturanperaturan syari'at yang belum jelas cara pelaksanaannya.

3. Sunnah Taqririyah, yaitu perbuatan seorang sahabat atau ucapannya yang dilakukan dihadapan atau sepengetahuan Nabi, tetapi tidak ditanggapi ataupun dicegah oleh Nabi. Kemudian diamnya Nabi itu, disampaikan oleh shabat yang menyaksikan kepada orang lain dengan ucapannya. Umpamanya, seorang sahabat memakan daging dhab di depan Nabi. Maka Nabi mengetahui apa yang dimakan oleh sahabat itu, tetapi Nabi tidak melarang atau menyatakan keberatan atas perbuatan itu. Kisah tersebut disampaikan oleh sahabat yang mengetahuinya dengan ucapannya, yaitu: "Saya melihat seorang sahabat memakan daging dhab di dekan Nabi, dan Nabi mengetahui tetapi beliau tidak melarang perbuatan itu". ${ }^{10}$ Biawak binatang liar yang boleh dimakan, sebab pernah di hidangkan dihadapan Rusul Saw. dan beliau tidak memakannya karena tidak biasa. Sebagian ulama ada yang mengharamkannya, antara lain ulama mazhab Hanafi.

\footnotetext{
${ }^{10}$ Dalam satu riwayat tindakan sahabat yang bernama Khalid bid Walid, dalam suatu jamuan makan, menyajikan masakan daging biawak dan mempersilahkan kepada Nabi Saw. untuk menikmatinya bersama undangan. Beliau menjawab: "Tidak (ma'af) berhubung binatang ini tidak terdapat di kampung kaumku, aku jijik padanya! Kata Khalid: "Segera aku memotongnya dan memakannya, sedangkan Rasulullah Saw. melihat kepadaku” (H.R. Muttaqun 'alahi). Fatchur Rahman, 9-10; bandingkan Amir Syarifuddin, Ushul Fiqh, Jld. I, Cet. III (Jakarta: Kencana Prenada Media Group, 2008), 83; Lihat pula, Abdul Aziz Muhammad Azzam, Fiqh Mu'amalat: Sistem Transaksi Dalam Fiqh Islam, Perterjemah Nadirsyah Hawari, Lc,MA, Cet.II (Jakarta: Amzah, 2014), 472.
} 
Untuk diketahui, di samping adanya syarat bahwa perkataan atau perbuatan yang dilakukan oleh seorang sahabat itu, tidak mendapat sanggahan dan disandarkan sewaktu Rasul masih hidup. Begitu juga seorang yang melakukan itu, hendaknya seorang yang taat kepada ajaran agama Islam. Sebab diamnya Rasul terhadap apa yang dilakukan atau diucapkan oleh orang kafir dan orang munafik, bukanlah berarti memberi persetujuan. Memang sering Rasul diam terhadap apa-apa yang dilakukan oleh orang kafir dan munafik, lantaran beliau tahu bahwa memang banyak petunjuk yang tidak memberi manfa'at kepada mereka.

Sebagaimana telah dijelaskan di atas, Sunnah merupakan sumber kedua dalam pembinaan hukum Islam di samping al-Qur'an, tetapi dengan syarat bahwa ia tidak berlawanan dengan al-Qur'an. Karena itu, segala yang terdapat dalam Sunnah, harus didapati kembalinya kepada suatu pokok dari pada alQur'an. Hal ini ditekankan lagi oleh Imam Syafi'i, yaitu "Segala apa yang telah dihukumkan oleh Rasulullah Saw. itu, semuanya dari apa yang telah dipahamkan dari al-Qur'an, karena semua Sunnah itu penjelasan bagi al-Qur'an. ${ }^{11}$ Selanjutnya Imam Asy-Syatibi mengatakan, dalam melakukan istimbath hukum, tidak seyogianya membatasi dengan memakai dalil al-Qur'an saja, tanpa memperhatikan penjabaran (syarah) dan penjelasan (bayan) dari Sunnah. Sebab dalam alQur'an banyak terdapat hal-hal yang masih global, seperti keterangan tentang shalat, zakat, haji, puasa, dan lainnya, sehingga tidak ada jalan lain, kecuali harus menengok keterangan dari sunnah. ${ }^{12}$ Al-Qur'an menjelaskan hukum mengenai bentuk kehidupan nyata yang diikuti oleh seorang muslim secara keseluruhan, ia menunjukkan dan

\footnotetext{
${ }^{11}$ Abdullah Siddik, Asas-asas Hukum Islam, Cet.I (Jakarta: Widjaya, 1982), 221.

${ }_{12}$ Muhammad Abu Zahrah, Ushul Fiqh, Terjemahan Saefullah Ma'shum ddk. Cet.II (Jakarta: PT. Pustaka Firdaus, 1994), 151.
}

menggariskan batas-batas dari berbagai segi kehidupan. Maka tugas Rasul Saw. untuk menyuguhkan ukuran-ukuran kehidupan praktis yang ideal dalam sinaran batas-batas yang dinyatakan al-Qur'an. Memang Rasulullah Saw. diutus terutama untuk mencontohkan ajaran alQur'an.

\section{Kedudukan Sunnah Sebagai Sumber Hukum}

Kedudukan Sunnah sebagai bayani (menjalankan fungsi menjelaskan hukum alQur'an), tidak diragukan lagi dapat diterima semua pihak, karena memang untuk itulah Nabi ditugaskan Allah SWT. Nabi Muhammad Saw. adalah seorang Rasul yang membawa risalah universal (rahmatan li al-'Alamin) dari Allah SWT. sebagai Nabi dan Rasul maka beliau merupakan teladan dan wajib untuk ditaati. Jumhur ulama berpendapat bahwa Sunnah berkedudukan sebagai sumber atau dalil kedua setelah al-Qur'an dan mempunyai kekuatan untuk ditaati serta mengikat untuk semua umat Islam. Mereka mengemukakan dalil-dalil yang menetapkan Sunnah itu harus di taati dan sebagai hujjah bagi kaum muslimin, di antaranya sebagai berikut:

Pertama, Banyaknya ayat-ayat al-Qur'an yang menyuruh dan memerintahkan kaum muslimin untuk menta'ati Rasul, dengan ungkapan yang berbeda. Ketaatan kepada Rasul sering dirangkaikan dengan keharusan menta'ati Allah. Umpamanya, firman Allah SWT:

"Hai orang-orang yang beriman, ta'atilah Allah dan ta'atilah Rasul-Nya dan ulil amri di antara kamu. Kemudian jika kamu berlainan pendapat tentang sesuatu, maka kembalikanlah ia kepada Allah (al-Qur'an) dan Rasul (Sunnahnya), jika kamu benarbenar beriman kepada Allah dan hari kemudian” (QS. an-Nisa': 59).

Kita dianjurkan agar mentaati Allah dan Rasul-Nya serta ulil amri (pemimpin). Ketaatan kepada Allah dan Rasul-Nya ini mengandung 
konsekuensi ketaatan kepada ketentuan-Nya yang terdapat dalam al-Qur'an, dan ketentuan Rasul Saw. yang terdapat dalam Sunnahnya. Selanjutnya, ketaatan kepada ulil amri sifatnya kondisional (tidak mutlak), karena betapapun hebatnya ulil amri itu, maka ia tetap manusia yang memiliki kekurangan dan tidak dapat dikultuskan. Atas dasar inilah mentaati ulil amri bersifat kondisional. ${ }^{13}$ Karena itu, jika produk ulil amri tersebut sesuai dengan ketentuan Allah dan RasulNya, maka wajib diikuti. Sedangkan jika produk ulil amri itu bertentangan dengan kehendak Allah, maka tidaklah wajib untuk mentaatinya. Allah SWT. juga menjelaskan, ketaatan kepada Rasulullah Saw. adalah sebagai tolak ukur, atau orang yang menta'ati Rasul berarti mentaati Allah, sebagaimana firman Allah:

"Barangsiapa yang mentaati Rasul itu, maka sesungguhnya ia telah mentaati Allah. Barang siapa yang berpaling (dari ketaatan itu), maka kami tidak mengutusmu untuk menjadi pemelihara bagi mereka” (QS. an-Nisa': 79).

Ayat tersebut mengadung petunjuk bahwa ketaatan kepada Rasulullah murupakan salah satu tolak ukur kepatuhan seseorang kepada Allah. ${ }^{14}$ Artinya, ketaatan kepada apa yang ditetapkan oleh Rasul Saw. dalam sunnahnya, merupakan manisfestasi dari ketaatan kepada Allah SWT. Begitu juga, ayat al-Qur'an menjelaskan bahwa memuji Rasulullah Saw. sebagai seorang yang agung akhlaknya (QS. al-Qalam: 4). Bahkan, alQur'an menjelaskan bahwa pada diri Rasulullah itu terdapat keteladanan yang baik atau uswatun hasanah (QS. al-Ahzab: 21).

Berdasarkan petunjuk ayat-ayat tersebut, jelas bahwa Rasulullah Saw. adalah teladan hidup bagi orang yang beriman. Maka cara meneladaninya adalah dengan mempelajari, memahami dan mengikuti berbagai macam

\footnotetext{
${ }^{13}$ Abuddin Nata, 67.

${ }^{14}$ Syuhudi Ismail, Metodologi Penelitian Hadits (Jakarta: Bulan Bintang, 1992), 7-8.
}

petunjuknya yang termuat dalam Sunnah (Hadis) beliau. ${ }^{15}$ Ayat di atas memberi petunjuk bahwa orang yang imam haruslah tunduk dan patuh kepada semua perintah dan keputusan yang ditetapkan oleh Rasulullah Saw. yang merupakan utusan Allah. Artinya, Allah menganggap tidak ideal iman seseorang yang tidak menyerah kepada keputusan Rasulullah Saw. Sementara itu, di pihak lain Allah mencela orang mukmin yang mengadakan pilihan menurut pendapatnya sendiri, pada hal Allah dan Rasul-Nya telah menetapkan ketentuannya (QS. al-Ahzab: 36).

Kedua, Sunnah Nabi Saw. pada prinsipnya adalah penyampaian (tabliqh) risalah Allah, dan Allah telah menugaskan kepada Nabi Saw. agar menyampaikan risalah itu kepada umatnya, sebagaimana firman Allah:

"Hai Rasul, sampaikan apa yang diturunkan kepadamu dari Tuhanmu, dan jika tidak engkau kerjakan, maka berarti engkau tidak menyampaikan (menjalankan) risalah-Nya" (QS. al-Maidah: 67).

Dengan demikian, apabila Sunnah secara keseluruhan merupakan panyampaian risalah Muhammad Saw. maka penerapan dalil sunnah, berarti sama dengan menerapkan syari'at Allah. Begitu pula ayat al-Qur'an menetapkan, apa yang dikatakan Nabi Saw. adalah berdasarkan wahyu, karena beliau tidak berkata berdasarkan kehendaknya sendiri, tetapi semua itu berdasarkan wahyu yang diturunkan Allah (QS. an-Najm: 34). Bila wahyu (al-Qur'an) mempunyai kekuatan sebagai dalil hukum, maka sunnah pun wahyu yang mempunyai kekuatan hukum untuk diikuti.

Ketiga, banyak hadis yang mewajibkan kita untuk mengikuti Nabi Saw. dalam segala hal, yaitu mengikuti secara umum terhadap segala sesuatu yang termasuk ajaran agama. Di anataranya, hadis dari Abu Hurairah bahwa Rasulullah Saw. bersabda:

\footnotetext{
${ }^{15}$ Ibid., 9.
} 
"Semua umatku akan masuk surga kecuali yang menolak (tidak mau). Para sahabat bertanya, siapa orang yang menolak itu wahai Rasulullah? Beliau menjawab, "Siapa yang menta'atiku, ia akan masuk surga dan siapa yang bermaksiat kepadaku, ia telah menolak (tidak mau) masuk surga" (H.R. Bukhari ). ${ }^{16}$

Berdasarkan uraian-uraian di atas, jelaslah ke-hujjah-an Sunnah sebagai sumber (dalil) hukum ditetapkan berdasarkan al-Qur'an. Ia juga wahyu seperti halnya al-Qur'an, dan Nabi hanyalah sebagai penyambung lidah dan penjelas hukum yang terkandung di dalamnya serta pelengkap terhadap syari'at. Kekuatan Sunnah sebagai sumber hukum ditentukan oleh dua segi, yaitu: dari segi kebenaran materinya dan dari segi kekuatan penunjukannya terhadap hukum. Adapun dari segi kebenaran materinya (wurudnya), kekuatan Sunnah mengikuti kebenaran pemberitaannya yang terdiri dari tiga tingkat, yaitu mutawatir, masyhur, dan ahad. ${ }^{17}$ Sunnah mutawatir ditinjau dari segi kuantitas shabat yang meriwayatkannya dari Nabi, dan juga kuantitas yang meriwayatkannya dari shabat dan seterusnya

\footnotetext{
${ }^{16}$ Syeikh Muhammad Nashiruddin al-Albani, 46.

${ }^{17}$ Berdasarkan cara penyampaiannya Sunnah (hadis) kepada kita, terbagi kepada: (1) Hadis Mutawatir, (2) Hadis Ahad. Namun, al-Hanafiyah (para pengikut mazhab Hanafi), memambah jenis ketiga, yaitu hadis masyhur atau mustafidh. Hadis mutawatir adalah yang diriwayatkan oleh orang banyak yang menurut adat dan akal mustahil mereka akan berdusta, karena banyaknya jumlah mereka atau ketsiqahan-nya untuk sebuah perkara yang bisa diindrai. Sedangkan hadis ahad adalah semua hadis yang tidak memenuhi persyaratan hadis muatawatir. Terkadang hanya diriwayatkan seorang perawi, disebut hadis gharib. Atau, diriwayatkan dua orang perawi atau lebih, disebut hadis aziz. Kadangkala diriwayatkan banyak perawi, tapi belum memenuhi derajat mutawatir, disebut hadis masyhur (mustafidh). Menurut pendapat yang shahih, hadis masyhur adalah bagian dari hadis ahad. Namun, Hanafiyah menjadikannya bagian tersendiri dan menetapkan untuk hadis masyhur hukum tertentu. Hadis masyhur, yaitu diriwayat dari Nabi oleh seorang atau dua orang lebih dari sahabat. Lihat Ibid., 24-27; lihat pula Alaiddin Koto, 7475.
}

adalah qath'i, dalam arti diyakani kebenarannya bahwa Sunnah itu betul-betul dari Nabi. Meskipun jumlah Sunnah mutawatir ini tidak banyak, namun mempunyai kekuatan sebagai dalil seperti kekuatan al-Qur'an.

Sedangkan secara logika, andaikata Sunnah itu bukan merupakan hujjah bagi kaum muslimin dan undang-undang yang harus mereka taati, niscaya mereka tidak akan dapat melaksanakan kewajiban yang diperintahkan Allah dalam al-Qur'an secara seksama. Sebab hukum-hukum al-Qur'an yang diwajibkan kepada manusia, umumnya bersifat mujmal. Al-Qur'an tidak menjelaskan tentang tata cara pelaksanaan hukum-hukumnya seperti perintah shalat. Maka di sinilah Sunnah (Hadis) menduduki posisi dan fungsi yang cukup signifikan dalam ajaran Islam untuk memberi penjelasan terhadap ke-mujmalan hukum-hukum al-Qur'an.

\section{Munculnya Istilah Sunnah Tasyri'iyah dan Ghairu Tasyri'iyah}

Sumber materi pokok hukum Islam adalah al-Qur'an dan Sunnah. Otoritas keduanya tidak berubah dalam setiap waktu dan keadaan. Tidak dapat disangkal, dalam kehidupan orang muslim, al-Qur'an dan Sunnah merupakan dua sumber ajaran agama yang mengatur banyak hal dan harus dipedomani dalam hidup. Allah berfirman:

\section{"Dan Kami turunkan al-Qur'an kepadamu supaya engkau menjelaskan kepada manusia apa-apa yang diturunkan kepada mereka, supaya mereka berpikir" (QS. an-Nahl: 44).}

Al-Qur' an tidak hanya berisikan persoalan aqidah dan ibadah, tetapi mencakup berbagai persoalan etika, moral, hukum dan sistem kehidupan lainnya. Ajarannya berlaku sepanjang masa dan bersifat universal untuk semua umat manusia. Ilmu pengetahuan modern membuktikan sekian banyak isyarat ilmiah dalam al-Qur'an, bahkan juga Sunnah, dan sejalan dengan penemuan ilmiah para ahli. 
Adapun Sunnah Nabawiyah, dari dahulu telah menjadi sasaran musuh-musuh Islam mulai dari orientalis dan misionaris, tatapi sunnah tetap eksis karena keimanan, kesakralan, cinta dan teladan yang telah terpatri dalam diri selorang mukmin. Adapun problem kontemporer yang banyak muncul adalah meragukan (tasykik) sunnah dari kalangan umat Islam sendiri. Barangkali tidak berlebihan, jika dikatakan bahwa di balik usaha-usaha tasykik itu adalah para orientalis, misionaris, kolonialis dan invader budaya dari luar. Kebebasan individual dalam berekspresi dan menyatakan pendapat dalam aqidah dan agama kini disalahpahami dan diekploitasi sedemikan rupa, untuk menjustifikasi intervensi dalam agama, hukum-hukum syari'ah dan bahkan Sunnah Nabi Saw. ${ }^{18}$

Beginilah problematika yang dihadapi leteratur klasik Islam (al-Turats al-Islamy) dan syari'ah. Ada segelintir orang memberikan panutannya hak untuk ber-ijtihad lalu mereka mengikutinya, tanpa peduli lagi dengan pendapatpendapat sahabat Nabi dan para ulama, meskipun panutaan mereka itu hanya berbekal ilmu yang minim atau hanya individu-individu dengan tangan kosong, tidak tahu prinsip-prinsip syari'ah lalu ia berkata, "kita juga mengambil hukum syari'ah dari al-Qur'an dan Sunnah". Atau, seorang ilmuwan yang spesialisasinya dalam bidang sains, lalu ia menganggap dirinya mampu mengkaji al-Qur'an dan Sunnah serta istimbat hukumnya. Padahal mereka tidak punya instrumen dasar untuk memhami pokok dan kaedah syari'ah. Ataupun mereka yang punya kepentingan politik dan maksud terselubung yang meneriakkan bahwa pintu ijtihad telah terbuka lebar, sehingga setiap mereka yang punya gelar pemikir Islam berhak untuk ber-ijtihad dalam syari'ah. Sedangkan mereka hanya berbekal mushaf, kitab-kitab hadis, mereka tidak hafal aya-

\footnotetext{
18 Muhammad Aniq Imam, "Sunnah Rasul antara Tasyri'iyah dan Ghairu Tasyri'iyah", dalam Jurnal Hermeneutik. 8, No.I (2012), 130.
}

ayat al-Qur'an, tidak hafal walaupun lima hadis, dan tidak bisa membedakan mana hadis yang shahih dan yang dhaif. ${ }^{19}$

Menurut Musa Syahin, pencetus dari pemetaan Sunnah tasyri'iyah dan ghairu tasyri'iyah adalah Syaikh Muhammad Syaltut. Beliau membahas permasalahan ini secara khusus sehingga menjadi rujukan para ulama dan pemikir setelahnya. Syaltut adalah orang pertama yang membuat distingsi Sunnah tasyri'iyah dan ghairu tasyri 'iyah ini. ${ }^{20}$ Statemen Syahin ini juga diamini oleh Syekh Yusuf al-Qardhawi yang mengatakan bahwa Syaltut adalah rujukan para ulama kontemporer, yang menulis tentang Sunnah dan klasifikasinya ke dalam tasyri'iyah dan ghairu tasyri'iyah. ${ }^{21}$ Namun, kalau dirunut lebih jauh lagi, sebenarnya sebelum Mahmud Saltut, banyak ulama yang menyinggung permasalahan ini seperti al-Qarafi (w. $684 \mathrm{H}$ ), Syah Wilayyullah ad-Dahlawi (w. $1176 \mathrm{H}$ ) dalam Hujjah alBalighah, Muhammad Rasyid Redha dalam tafsir al-Manar. ${ }^{22}$ Kemudian diikuti oleh ulama dan pemikir kontemporer yang ikut membahas tentang terminologi Sunnah Gharu Tasyri'iyah.

Di samping itu, sikap umum umat Islam memandang hadis yang terumuskan dari Sunnah yang hidup saat itu mempunyai harga mati yang tidak dapat ditawar-tawar lagi, dan para ulama salaf pun kurang memiliki perhatian khusus dalam kajian tentang Sunnah Tasyri'iyah dan Ghairu Tasyri'iyah. Mereka cenderung memandang semua Sunnah sebagai syari' at yang berketetapan hukum (al-Sunnah Kulluha Tasyri'). Mereka cenderung pada generalisasi Sunnah sebagai

\footnotetext{
${ }^{19}$ Musa Syahin Lasyin, As-Sunnah wa at-Tasyri' (Kairo: Majma' al-Buhuts al-Islamiyyah, 1411), 11; Lihat pula, Ibid., 131.

${ }^{20}$ Musa Syahin Lasyin, As-Sunnah Kulluha Tasyri' (Qatar: Qatar University, t.th), 38.

${ }^{21}$ Yusuf al-Qardhawi, As-Sunnah an-Nabawiyyah Masdaran li al-Ma'rifah wa al-Hadharah (Kairo: Dar alSyuruq, 1998), 12.

${ }^{22}$ Rasyid Ridha, Tafsir al-Manar (Kairo: Al-Hai'ah alMisriyyah al-'Ammah li al-Kitab, 1990), 303; Lihat juga, Muhammad Aniq Imam, 131-132.
} 
syari'at atau kebenaran mutlak dan sebagai produk jadi (taken for granted). ${ }^{23}$

Dengan demikian, pada gilirannya agak sulit membedakan mana Sunnah yang bersifat mutlak, terutama yang berkaitan dengan 'aqidah dan ibadah yang terbatas dari ikatan ruang dan waktu, dan mana pula Sunnah yang bersifat nisbi terkait mu'amalah, pengalaman pribadi dan tradisi (kultur) lokal Arab yang terkait oleh ruang waktu.

\section{Sunnah Tasyri'iyah dan Ghairu Tasyri'iyah}

Di lihat dari satu segi Sunnah adalah segala upaya yang dikatakan Nabi, diperbuat atau yang di akuinya. Namun, di sisi lain umat dituntut untuk mengikuti semua Sunnah Nabi Saw. Maka di antara Sunnah itu, ada yang mesti di ikuti (Tasyri'iyah) dan ada pula yang tidak mesti di ikuti (Ghairu Tasyri'iyah), bahkan ada yang dilarang untuk mengikutinya. Adapun sabda, perbuatan dan taqrir Rasulullah Saw. adalah sari'at yang harus dita'ati oleh kaum muslimin selama sabda dan perbuatan maupun taqrir tersebut datang (keluar) dari beliau sendiri sebagai Rasul dan memang dimaksudkan sebagai undangundang umum yang wajib dita'ati. Akan tetapi kerena beliau juga sebagai manusia biasa, hanya saja beliau itu dipilih oleh Allah sebagai utusanNya, maka sudah barang tentu ada beberapa jenis perkataan dan perbuatannya bukan termasuk syari'at yang harus dita'ati dan diikuti. Dengan demikian, dalam hal ini ulama mengelompokkan Sunnah itu kepada dua kelompok, yaitu Sunnah Tasyri'yah dan Ghairu Tasyri'iyah.

\section{Kriteria Sunnah Tasyri'iyah}

Sunnah Tasyri'iyah (Sunnah yang berdaya hukum) yakni Sunnah yang mesti diikuti atau mengikat untuk di ikuti. Adapun Sunnah Tasyri'iyah itu dengan kriteria sebagai berikut:

a. Ucapan dan perbuatan yang muncul dari Nabi, dalam bentuk penyampaian risalah dan

\footnotetext{
${ }^{23}$ Muhammad aniq Imam, 132.
}

penjelasan terhadap al-Qur'an, seperti menjelaskan apa-apa yang dalam al-Qur'an masih bersifat belum jelas, membatasi yang umum, memberi qayid yang masih bersifat mutlak, menjelaskan bentuk ibadah, halal dan haram, 'aqidah dan akhlak. Ucapan dan perbuatan Nabi dalam kapasitasnya sebagai seorang Rasul, termasuk Sunnah berdaya hukum yang wajin di ikuti. ${ }^{24}$ Sebagai salah satu bukti bahwa seseorang benar-benar mentaati dan mengikuti Rasulullah Saw. maka apa yang datang dari beliau yang terkait berbagai masalah agama adalah mutlak untuk diikuti, dan apa yang bukan dari Rasul terkait masalah agama adalah tertolak.

b. Ucapan dan perbuatan yang timbul dari Nabi, dalam kedudukannya sebagai imam dan pemimpin umat Islam, seperti mengirim pasukan untuk jihad, membagi harta rampasan, menggunakan bait al-mal, mengikat perjanjian dan tindakan lain dalam sifatnya sebagai pemimpin. Namun, Sunnah Tasyr' $i$ dalam bentuk ini, tidaklah berlaku secara umum untuk semua orang, dan dalam pelaksanaannya tergantung kepada izin atau persetujuan imam atau pemimpin.

c. Ucapan dan perbuatan Nabi dalam kedudukannya sebagai hakim (qadhi) yang menyelesaikan persengketaan di antara umat Islam. Adapun daya hukum dalam bentuk ini, tidak bersifat umum dan hanya dapat dilakukan oleh perorangan dengan penunjukan dari imam atau penguasa. ${ }^{25}$

Sunnah Tasyri'iyah (Sunnah berdaya hukum) yang mesti untuk diikuti sebagaimana tersebut di atas, secara garis besar mengandung berbagai bidang sebagai berikut:

\section{a. 'Aqidah}

Bidang 'aqidah ini dibatasi oleh Islam, dalam hal perbedaan antara iman dan kafir,

\footnotetext{
${ }^{24}$ Amir Syarifuddin, 101-102

${ }^{25}$ Ibid., 102.
} 
yang berhubungan dengan Allah dan sifatsifat-Nya, para Rasul dan hari kiamat. Sunnah tidak dapat menetapkan dasar 'aqidah karena 'aqidah ini menimbulkan kepercayaan, sedangkan kepercayaan itu adalah keyakinan yang pasti. Tidak ada yang mungkin menghasilkan keyakinan yang pasti itu, kecuali yang pasti pula. Sunnah yang pasti (qath'i) ialah Sunnah yang baik dari segi lafaznya, wurud-nya maupun dari segi dalalah-nya adalah qath'i atau pasti. Sunnah yang pasti hanyalah Sunnah menurut persyaratan mutawatir yang jumlah sangat terbatas. ${ }^{26}$ Sunnah mutawatir adalah hadis Nabi Saw. diriwayatkan oleh sekian banyak orang, baik pada tingkat pertama (sahabat), tingkat kedua, maupun pada tingkat selanjutnya, dan kesemuanya mustahil dapat berdusta. Karena itu, Sunnah mutawatir dikategorikan sebagai qath'i al-wurud (pasti sumbernya). Dengan demikian, Sunnah mutawatir dalam kedudukannya sebagai sember hukum sama seperti al-Qur'an.

Hukum-hukum 'aqidah (i tiqadiyyah), yaitu hukum yang berkaitan tentang Zat Allah, segala sifat-Nya dan wajib beriman kepadaNya, dinamakan ilahiyyat. Jika berkaitan dengan para Rasul dan beriman kepadanya dinamakan nubuwwat, dan jika berkaitan dengan malaikat dan segala perkara akhirat, baik berupa hari kebangkitan, hisab, mizan, surga dan neraka, dinamakan sam 'iyyat karena termasuk perkara gaib yang tidak dapat diketahui oleh seseorang, kecuali dengan cara mendengar dari para Nabi dan Rasul. Semua perkara gaib ini adalah menjadi objek kajian ilmu tauhid dan ilmu kalam.

\section{b. Akhlak}

Dalam Sunnah atau Hadis, banyak sekali disampaikan Nabi mengenai hikma-

${ }^{26}$ Ibid., 102; bandingkan, Abdul Aziz Muhammad Azzam, $1-3$. hikmah, adap sopan santun dalam pergaulan ataupun nasehat, baik secara langsung maupun dalam bentuk pujian tentang keadilan, kebenaran dan menepati janji, dan atau celaan terhadap perbuatan-perbuatan buruk yang dilakukan umat. Sunnah tersebut menuntut munculnya manusia yang sempurna. ${ }^{27}$ Semua yang muncul dari Sunnah dalam bentuk akhlak ini, pada umumnya mempunyai dasar dan rujukan dalam al-Qur'an, Sedangkan Sunnah yang datang kemudian, hanya bersifat menjelaskan atau merincinya. Mengkaji secara spesifik tentang etika, yaitu pendidikan dan pembersihan jiwa (mental), budi pekerti luhur yang harus dimiliki seseorang, serta sifat-sifat buruk yang harus dihindari.

\section{c. Hukum-Hukum Amaliah}

Hukum amaliah berhubungan dengan penetapan bentuk-bentuk ibadah, pengaturan mu'amalah antar manusia, memisahkan hakhak dan kewajiban, menyelesaikan persengketaan di antara umat secara bijak dan adil. Maka hukum-hukum yang diperoleh dari sunnah dalam bentuk inilah yang disebut "Fiqh Sunnah", sedangkan hadisnya sendiri disebut "Hadis Ahkam". Karena itu, Sunnah (hadis) dalam bentuk inilah yang dijadikan Sumber hukum oleh para ahli ushul dan fiqh sesudah al-Qur'an. ${ }^{28}$ Dari situlah mereka meng-istinbath-kan hukum dan mencari penjelasan tentang petunjuk-petunjuk alQur'an yang menyangkut masalah hukum. Dalam syari'at, semua aturan hukum tentang tata cara bermu'amalah dengan Tuhan maupun dengan manusia, maka diberlakukan dengan nama Allah. Perlanggaran terhadap hukum "duniawi", seperti berbohong atau

${ }^{27}$ Ibid., 103; bandingkan, Umar Shihab, Kontekstualitas alQur'an, Kajian Tematik Ayat-ayat Hukum dalam alQur'an, Cet.III (Jakarta: Penamadani, 2005), 331-335.

${ }^{28}$ Ibid., 103; bandingkan, Muhammad Abdi Almaktsur dan Mardiana, Ilmu Fiqih (Suatu Pengantar) (Pekanbaru: Suska Press, 2011), 7-8. 
curang dalam jual beli, tetap dinilai sebagai kesalahan, kendati yang tahu hanya dirinya sendiri. Dengan kata lain, hukum-hukum amaliah (praktis), yaitu hukum yang berkaitan tentang perbuatan hamba, seperti wajibnya shalat, zakat, haji, halalnya jual beli dan lainnya, menjadi objek kajian ilmu Fiqh.

\section{Problematika seputar Sunnah Ghairu Tasyri'iyah}

Nabi Muhammad Saw. adalah seorang Rasul yang membawa risalah universal (rahmatan li al- 'Alamin) dari Allah SWT. sebagai Nabi dan Rasul, beliau merupakan teladan (uswatun hasanah). Sebagai Rasul beliau juga wajib untuk ditaati, sehingga apa yang datang dari beliau hendaklah diterima dengan keta'atan sepenuh hati sebagai bukti seorang dianggap beriman, dan apa yang beliau larang haruslah dihindari. Namun, selain sebagai seorang Nabi dan Rasul, beliau juga adalah manusia sebagaimaana manusia lainya seperti dijelaskan dalam ayat-ayat al-Qur'an. Karena itu, beliau juga memiliki kebutuhan jasmani dan rohani, memiliki keinginan dan selera serta mempunyaii kebiasaan-kebiasaan dalam kehidupan sehari-hari.

Adapun ketetapan beliau dalam kapasitasnya sebagai Rasul merupakan sumber syari' at yang tidak diperdebatkan, namun apakah segala yang datang dari beliau sebagai manusia biasa dalam konteks bahwa sebagian perbuatan dan perkataan beliau yang muncul dari sifat kemanusiaannya (jabillah Basyariyyah) juga merupakan sumber syarai'at yang mengikat? Pertanyaan inilah yang memunculkan istilah "sunnah ghairu tasyri'iyah".

Istilah sunnah ghairu tasyri'iyah memamang masih diperdebatkan, ada yang pro yang memberikan beberapa definisi dan ada yang kontra yang menganggap istilah sunnah ghairu tasyri'iyah itu tidak dikenal pada masa salaf alsalih dan ia hanya rekayasa kaum modernis dan rasionalis. Namun, setelah dilakukan kajian mendalam maka ada beberapa ulama yang mendukung pemahaman tentang adanya sunnah ghairu tasyri'iyah, walaupun mereka berbedabeda dalam mendefinisikan sunnah ghairu tasyrri'iyah itu sendiri. Sebab tidak ada ramburambu yang jelas yang $\mathrm{b}$ isa dijadikan pedoman untuk distingsi sunnah tasyri'iyah dan ghairu tasyri'iyah. Karena itu, masing-masing memiliki standar yang berbeda dan tidak ada kesepakatan bersama dalam memberikan satu definisi yang jelas (jami' mani'). ${ }^{29}$ Ada beberapa istilah yang dipakai para ulama yang dapat dikategorikan sunnah ghairu tasyri'iyah, yaitu sunnah yang tidak harus diteladani (sunnah laisa fi hi uswah), sunnah yang tidak harus ditiru (laisa fi hi ta'assin), sunnah yang tidak harus diikuti (la biha Iqtida'), sunnah yang tidak mengandung taqarrub kepada Allah (laisat bi qurbah) dan lainnya.

Dari berbagai definisi yang sudah dikaji dan ditinjau dari berbagai aspeknya, sunnah ghairu tasyri'iyah adalah sunnah Nabi yang tidak memiliki ketetapan hukum yang mengikat, berkaitan dengan perintah dan larangan Nabi yang bersifat anjuran (al-Irsyad) yang tidak harus diikuti, perbuatan Nabi murni (al-Fi'l alMujarad) tanpa ada indikasi (qarinah) ibadah, perbuatan Nabi sebagai manusia (al-Fi'l alJibilly), perbuatan dan perkataan Nabi yang berdasarkan pengalaman (at-Tajribah) serta perbuatan dan perkataan Nabi dalam kapasitas sebagai Kepala Negara dan Hakim (al-Imam wa al-Qadhi). ${ }^{30}$

Menurut Syahin, sebagaimana dikutip Muhammad Aniq Imam, bila dilihat dari awal mula klasifikasi Sunnah dalam dua istilah (tasyri'iyah dan ghairu tasyri'iyah) disebabkan misunderstanding (su'al-Fahm) atau perbedaan sudut pandang (wijhat an-Nadhar) dalam memahami Sunnah itu sendiri. Terminologi ghairu tasyri'iyah dalam banyak hal mengandung kesan stigmatik, terutama bila dihadapkan kepada konstruksi dasar pengetahuan konservatif dalam

\footnotetext{
${ }^{29}$ Muhammad Aniq Imam, 133.

${ }^{30}$ Ibid., 134.
} 
memahami agama Islam, karena mengakibatkan pergeseran pemahaman sunnah yang sudah baku di kalangan para generasi pendahulu (salaf ummah). Mereka tidak mengenal istilah ini, bahkan pencetusnya bisa dianggap telah mengada-ada (bid'ah) serta mengesampingkan dimensi Sunnah yang menyeluruh dan komplit (syamilah wa mutakamilah). Sunnah yang harus disampaikan kepada satu setengah milyar umat Islam di penjuru bumi yang memiliki ragam latar belakang, tradisi, kultur dan budaya. Argumen yang dilontarkan oleh mereka yang pro sunnah ghairu tasyri'iyah adalah lemah, kebanyakan dilandasi oleh kaburnya pemahaman mereka terhadap produk hukum yang lazim dilaksanakan dan yang tidak lazim dilaksanakan. ${ }^{31}$

Adapun solusi yang ditawarkan Syahin, supaya memahami Sunnah secara proporsional, dalam berinteraksi dengan sunnah adalah mengedepankan pemahaman kontekstual dari pada pemahaman tekstual. Pemahaman kontekstual ini dimaksudkan agar dapat memperoleh pemahaman yang komprehensif tentang Sunnah. Bagi Syahin, dalam memahami sunnah harus memperhatikan konteks dan bukan hanya teksnya saja. Memperhatikan situasi dan kondisi yang mengiringi asbab wurud suatu hadis adalah sangat urgen dalam memahami sunnah Nabi. Karena dua hal ini merupakan unsur asasi bagi dikeluarkannya suatu hukum. Di dalam sunnahnya, Rasulullah melakukan perbuatanperbuatan sesuai dengan situasi dan kondisi tertentu. Mungkin kalau kondisi itu berubah, Rasulullah juga akan mengubah perbuatannya tersebut. ${ }^{32}$ Umpamanya, Rasulullah makan dengan jari-jari tangannya secara langsung,

\footnotetext{
${ }^{31}$ Ibid., 134-135.

${ }^{32}$ Menurut Syahin, ada tiga penyakit yang menjangkiti umat Iskam dalam memahami Sunnah, hingga menimbulkan perpecaahan umat ini dalam beberapa sakte dan aliran. Masing-masing paham mengaku paling benar dan yang lain adalah salah. Pertama, pemahaman leberal terhadap Sunnah, pemahaman yang mengeluarkan sebagian perbuatan Rasul Saw. dari nilai tasyri'nya. Menyamakan
}

menghisapi jari-jarinya setelah selesai makan, dan memerintahkan para sahabatnya untuk melakukan itu. ${ }^{33}$ Adapun Rasulullah melakukan dan memerintahkan itu karena kondisi menuntut demikian, di mana pada masa itu beliau hidup di gurun pasir yang minim sekali suplai airnya, sehingga alternatif lain untuk membersihkan sisa makanan adalah dengan menghisap jari-jarinya. Begitu pula Rasulullah berwudhu dengan sebotol air, mandi dengan tiga botol air. Kalau seandainya Rusulullah hidup di zaman sekarang, di hadapannya tersedia kamar mandi dengan kran air dingin, air panas, sabun beku dan cair, mesin pengering, sudah barang tentu Rasulullah tidak akan menghisap jarinya guna membersihkan sisa makanan yang menepel, beliau tentu akan cuci tangan dengan memakai sabun dan cream, beliau akan mandi di bawah shower dengan air yang banyak dan menggunakan aneka warna cream serta pewangi yang telah tersedia untuk itu.

Berdasarkan ketarangan di atas, dapatlah dipahami bahwa Sunnah Ghairu Tasyri'iyah (Sunnah yang tidak berdaya hukum), yaitu Sunnah yang tidak harus diikuti dan karenanya tidak mengikat untuk ditaati dan diteladani. Adapun Sunnah Ghairu Tasyri'iyah di antaranya:

a. Ucapan dan perbuatan Nabi yang timbul dari hajat insani, dalam kehidupan keseharian Nabi dalam pergaulan, seperti makan, tidur, berkunjung, sopan dalam bertamu, cara berpakaian dan lainnya ucapan dan perbuatan

sebagian perbuatan beliau dengan perbuatan manusia biasa yang tidak dikawal (dibimbing) oleh wahyu, sehingga perbuatannya tidak memiliki ketetapan hukum (ghairu tasyri'iyah). Kedua, pemahaman yang ekstrim dalam mengkultuskan perkara-perkara mubah yang dilakukan Nabi, dan mereka tidak bisa membedakan mana yang berketetapan hukum wajib, sunnah, makruh dan mubah, sehingga mereka yang menganut paham ini beranggapan bahwa semua yang pernah dilakukan Nabi adalah lazim dan harus diikuti. Ketiga, memahami Sunnah tanpa memperhatikan latar belakang (asbab al-wurud), stuasi dan kondisi yang mengiringi munculnya Sunnah Nabi Saw. Lihat, Ibid., 143-144.

${ }^{33}$ HR. Bukhari, No. 5140. 
Nabi sebagai manusia biasa. Tetapi kalau perbuatan tersebut memberi suatu pertunjuk tentang tata cara makan, minum, berpakaian dan lainnya, maka menurut pendapat yang lebih baik, sebagaimana dikemukakan oleh Abu Ishaq dan kebanyakan para Mjuhaddisin hukumnya "Sunnat". Misalnya, "Konon Nabi Saw. memakai jubah (gamis) sampai di atas mata kaki" (HR. al-Hakim). ${ }^{34}$

b. Ucapan dan buatan Nabi yang timbul dari pengalaman pribadi, kebiasaan dalam pergaulan, seperti urusan pertanian, kesehatan badan, cara berjual beli dan memelihara hewan ternak. Atau tindakan beliau yang berdasarkan suatu kebijaksanaan yang bertalian dengan masalah keduniaan. Misalnya, ketika Rasul mengetahui penduduk Madinah menyerbukan bunga korma agar produktivitasnya meningkat, dan beliau menyarankan supaya perbuatan itu tidak diteruskan, maka penduduk Madinah menghentikannya, tetapi hasilnya sangat mengecewakan. Setelah hal kitu diketahuinya maka beliau bersabda: "Serbukkanlah kormamu lagi! Kamu lebih mengetahui urusan-urusan keduniaan yang kamu geluti", (HR. Muslim).

Hadis tersebut dengan berbagai versinya menunjukkan bahwa Nabi memberikan pendapat dalam salah satu persoalan keduniaan yang tidak dikuasainya. Beliau adalah salah seorang dari penduduk Mekah yang tidak berprofesi sebagai petani korma, sebab kota Mekah adalah daerah tandus yang tidak sesuai untuk pertanian dan perkebunan. Saran beliau saat itu oleh para sahabatnya dipandang sebagai ajaran agama yang harus diikuti, tetapi kemudian ternyata

\footnotetext{
${ }^{34}$ Abu'l-Fida' Isma'il bin Kasir, Tafsir Ibnu Kasir, Jld. III (Kairo: Daru Ihyai'l Kutubi 'Arabiyah, t.th), 499-500; bandingkan, 'Abdul Qadir 'Audah, Tasyri'ul Jinai'l Islamy (Kairo: Maktabah Darrul 'Arubah, t.th), 177; Lihat pula Fatchur Rahman, 9.
}

saat panen tiba hasilnya tidap seperti yang diharapkan. Dari sini kemudian, Rasul menjelaskan dalam soal teknis yang tidak terkait dengan persoalan agama, maka para ahli di bidangnya lebih tahu dari Rasul. Karenanya, pakar hadis terkemuka dan menyusun kitab penjelasan (syarah) Shahih Muslim, Imam Nawawi, meletakkan hadis tersebut di bawah judul, "Bab kewajiban mengikuti sabda Rasul yang berupa syari'at agama, bukan persoalan keduniaan yang disampaikan Rasul berdasarkan pendapatnya". 35 Pada bidang keduniaan hadis tidak berimplikasi hukum, tatapi dari contoh di atas, dapat dipahami bahwa titik krusial dalam teksteks keagamaan adalah pada penafsirannya, terutama yang terkait dengan pola hubungan lafal (teks) dan makna (batin).

c. Ucapan dan perbuatan Nabi yang timbul dari tindakan pribadi dalam keadaan dan lingkungan tertentu, seperti penempatan pasukan, pengaturan barisan dan penentuan tempat dalam perperangan. ${ }^{36}$ Atau, segala sesuatu yang keluar dari Nabi Saw. yang semata hanya sebagai kebijaksanaan dalam masalah keduniaan. Umpamanya, tindakan beliau diwaktu perang Badar menempatkan satu devisi angkatan perang di suatu tempat yang strategis menurut ijtihad beliau sendiri. Karena hasil ijtihad-nya, kemudian di usulkan oleh salah seorang sahabat supaya di pindahkan ke tempat yang lebih strategis, maka usulan itu terima oleh Rasul.

Semua yang dinukilkan dari Nabi dalam tiga bentuk di atas, tidak mempunyai daya hukum mengikat yang mengandung tuntutan atau larangan. Maksudnya umat boleh saja mengikuti apa yang dilakukan Nabi itu, tapi hukumnya adalah Sunnat, namun sifatnya tidak mengikat untuk di ikuti dan tidak mendapat celaan bagi

\footnotetext{
${ }^{35}$ Muchlis M. Hanafi, 4.

${ }^{36}$ Amir Syarifuddin, 1011; Lihat pula, Mukhtar Yahya dan Fatchurrahman, 56-58.
} 
yang meninggalkannya. Untuk diketahui, bahkan ada sesuatu yang datang atau keluar dari Rasulullah Saw. dan ditunjukan oleh dalil syara' bahwa apa yang dilakukan beliau itu hanya khusus bagi beliau sendiri. Bukanlah merupakan undangundang umum yang berlaku bagi semua umat Islam. ${ }^{37}$ Umpamanya, tindakan beliau mengawini wanita tanpa mahar. Perbuatan itu dilakukan karena beliau mendapat dispensasi dari Allah, sebagaimana tercantum dalam (QS. al-Ahzab: 50). Demikian juga Rasulullah Saw. diperbolehkan mengawini wanita lebih dari 4 orang dan lainnya. Adanya pengecualian sebagian dari perbuatan Rasul Saw. tidaklah mengurangi ketentuan tentang perbuatan Rasul menjadi nash syara' yang harus di ikuti dan di teladani umat Islam, disebabkan ada suatu dalil menunjukkan perbuatan itu hanya spesifik bagi beliau sendiri.

Perlu diketahui, dalam pemahaman sunnah dan penerapannya ada hal yang mendasar yang mesti diperhatikan. Jangan kita berprasangka bahwa selagi mengamalkan sunnah adalah wajib, lalu secara otomatis kita wajib mengamalkan semua yang masuk dalm kategori sunnah Nabi. Tentu tidak demikian adanya, karena mengamalkan sunnah itu ada derajat dan tingkatannya. Apa yang berketetapan hukum wajib, kita wajib mengamalkannya, apa yang bertetapan hukum sunnah, maka kita disunnahkan mengamalkannya dan apa yang berketatapan hukum mubah, kita bebas memilih untuk mengamalkan atau tidak mengamalkannya. Sementara apa yang di larang oleh Rasulullah dan berketetapan hukum haram, maka kita harus menjauhinya. Begitu pula apa yang dilarang oleh Rasulullah dan berketetapan hukum makruh, kita

\footnotetext{
${ }^{37}$ Perkara yang menjadi khususiat, yaitu tertentu bagi Rasulullah Saw. saja, tidak mesti ditiru dan diteladani, dan bahkan dilarang kita mengikutinya. Seperti memperhubungkan puasa siang dan malam, tida berbuka. Beristri lebih dari 4 orang. Dalam hal itu, tidaklah harus kita meneladaninya karena khusus untuk beliau sendiri. Lihat Ibid., 58; bandingkan, Abdul Karim Amrullah, Pengantar Ushul Fiqh (Jakarta: Pustaka Panjimas, 1984), 41-42.
}

juga menjauhinya. Dengan demikian, dalam halhal ini kita mematuhi dan mentaati apa yang datang dari Nabi (Sunnah Nabi).

\section{Kesimpulan}

Nabi Muhammad Saw. adalah seorang Rasul yang membawa risalah universal (Rahmatan li al-'Alamin) dari Allah SWT. Sebagai Nabi dan Rasul beliau merupakan teladan (uswatun hasanah), dan sebagai Rasul beliau juga wajib untuk ditaati. Satu hal yang harus diyakini, pada umumnya Sunnah Rasul, baik yang berbentuk ucapan, perbuatan dan ketetapannya mempunyai implikasi hukum yang mesti diikuti (Sunnah Tasyri'iyah). Umpamanya, perbuatan yang muncul dari beliau dalam bentuk penyampaian risalah dan penjelasannya terhadap al-Qur'an tentang beberapa masalah ibadah yang bersifat umum dan mutlak, seperti menjelaskan bentuk dan tata cara shalat dan lainnya. Karena itu, apa yang datang dari beliau hendaklah diterima dengan ketaatan sepenuh hati sebagai bukti seseorang dianggap beriman dan apa yang beliau larang haruslah dihindari. Namun, selain sebagai seorang Nabi dan Rasul beliau juga adalah manusia sebagaimana manusia lainnya seperti dijelaskan dalam ayat al-Qur'an. Beliau tentu juga memiliki keperluan jasmani dan rohani, memiliki keinginan dan selera serta mempunyai kebiasaankebiasaan dalam kehidupan sehari-hari. Apakah semua yang datang dari beliau sebagai manusia biasa dalam konteks bahwa sebagian perbutan dan perkataan beliau yang muncul dari sifat kemunusiaannya (Jibillah Basyriyyah) juga merupakan sumber syari' at yang mengikat. Hal inilah yang menjadi perdebatan di kalangan ulama, sehingga memunculkan wacana Sunnah tasyri'iyyah dan ghairu tasyri'iyyah, pada dasarnya adalah berpijak dengan prinsip pemisahan antara apa yang bersumber dari wahyu Tuhan (Ilahi) dengan apa yang bersumber dari pada nalar manusia (human/basyari). Istilah Sunnah ghairu tasyri'iyah masih diperdebatkan (ada yang pro dan ada yang kontra) dan tidak 
dikenal pada masa salaf al-salih. Munculnya istilah Sunnah ghairu tasyri'iyah pada akhir abad $14 \mathrm{H}$, di antara pencetus Syekh Muhammad Syaltut.

Sunnah ghairu tasyri'iyah, yaitu Sunnah yang tidak mesti diikuti dan tidak mengikat. Misalnya ucapan atau perbuatan Nabi Saw. yang timbul dari hajat insani dalam kehidupan keseharian beliau, seperti makan, cara berpakaian, urusan pertanian dan lainnya. Kalau perbuatan tersebut memberi suatu petunjuk tentang tata cara makan dan minum, berpakaian dan lainnya, maka menurut pendapat jumhur ulama hukum mengikutinya adalah sunnat. Bahkan ada perkara yang (khususiat), yaitu tertentu bagi Nabi Saw. sendiri dan bukan merupakan undang-undang yang berlaku bagi seluruh umat Islam, seperti Rasul Saw. diperbolehkan mengawini wanita lebih dari 4 orang dan lainnya.

\section{Daftar Kepustakaan}

Abdul Karim Amrullah. Pengantar Ushul Fiqh. Jakarta: Pustaka Panjimas, 1984.

Abdullah Siddik. Asas-asas Hukum Islam. Cet.I. Jakarta: Widjaya, 1982.

Abuddin Nata. Metodologi Studi Islam. Cet. IX. Jakarta: PT. Raja Grafindo Persada, 2004.

Ahmad Hasan. Pintu Ijtihat Sebelum Tertutup. Bandung: Pustaka, 1984.

al-Albani, Syeikh Muhammad Nashiruddin. Berhujjah Dengan Hadits Ahad; dalam Masalah Akidah dan Hukum. Penterjemah Darwis, Lc, Cet. I. Jakarta: Darus Sunnah Press, 2008.

al-Qardhawi, Yusuf. Al-Qur'an dan al-Sunnah. Terj. Bahrudin Fanani. Jakarta: Rabbani Press, 1997.

al-Qardhawi, Yusuf. As-Sunnah an-Nabawiyyah
Masdaran li al-Ma'rifah wa al-Hadharah. Kairo: Dar al-Syuruq, 1998.

al-Qardhawi, Yusuf. Sunnah dan Bid'ah. Cet. IV. Jakarta: Gema Insani, 2004.

al-Siba'i, Musthafa Al-Sunnah wa Makanatuha fi al Tasyri',

at-Tarmusy, Muhammad Mahfudh. Manhaj Dzawin Nadhar. Kairo: Mathba'ah Sa'adah, t.th. Alaiddin Koto. Ilmu Fiqh dan Ushul Figh. Cet.IV. Jakarta: PT.Raja Grafindo Persada, 2011.

Amir Syarifuddin. Ushul Fiqh. Jld. I. Cet. III. Jakarta: Kencana Prenada Media Group, 2008.

'Audah, 'Abdul Qadir. Tasyri'ul Jinai'l Islamy. Kairo: Maktabah Darrul 'Arubah, t.th.

Azzam, Abdul Aziz Muhammad. Fiqh Mu'amalat: Sistem Transaksi dalam Fiqh Islam. Perterjemah Nadirsyah Hawari, Lc,MA, Cet.II. Jakarta: Amzah, 2014.

Fatchur Rahman. Ikhtishar Mushthalahu'l Hadits. Cet. VII. Bandung: PT. Al-Ma'arif, 1991.

Ibrahim, Duski. Metode Penetapan Hukum Islam: Membongkar Konsep al-Istiqra, alMa'nawi Asy-Syatibi. Yogyakarta: ArRuzz Media, 2008.

Kasir, Abu'l-Fida' Isma'il bin. Tafsir Ibnu Kasir. Jld. III. Kairo: Daru Ihyai'l Kutubi 'Arabiyah, t.th.

Khan, Sadiq Hasan. Husul al-Ma'mul fi 'ilm alUshul. Kairo: Dar al-Fikr al-'Arabi, 1284 $\mathrm{H}$.

Lasyin, Musa Syahin. As-Sunnah wa at-Tasyri'. Kairo: Majma' al-Buhuts al-Islamiyyah, 1411.

Lasyin, Musa Syahin. As-Sunnah Kulluha Tasyri'. Qatar: Qatar University, t.th.

Muchlis M. Hanafi. "Pola interaksi dengan alQur'an dan Sunnah", Makalah 
disampaikan pada Kuliah Umum Jurusan Tafsir Hadis UIN Sunan Kalijaga Yogyakarta, 2008, 2-3.

Muchtar Yahya dan Fatchurrahman. Dasar-dasar Pembinaan Hukum Fiqh Islami. Bandung: PT. Al-Ma'arif, Bandung, 1983.

Muhammad Abdi Almaktsur dan Mardiana. Ilmu Fiqih (Suatu Pengantar). Pekanbaru: Suska Press, 2011.

Muhammad Aniq Imam. "Sunnah Rasul antara Tasyri'iyah dan Ghairu Tasyri'iyah". dalam Jurnal Hermeneutik. 8, No.I (2012), 130.

Nazar Bakry. Fiqh dan Ushul Fiqh. Cet. IV. Jakarta: PT.Raja Grafindo Persada, 2003.

Rachmat Syafe'i. Ilmu Ushul Fiqh. Cet. I.
Bandung: CV. Pustaka Setia, 1999.

Ridha, Rasyid. Tafsir al-Manar. Kairo: Al-Hai'ah al-Misriyyah al-‘Ammah li al-Kitab, 1990.

Satria Effendi \& M.Zein. Ushul Fiqh. Jakarta: Kencana, 2005.

Syuhudi Ismail. Metodologi Penelitian Hadits. Jakarta: Bulan Bintang, 1992.

Umar Shihab. Kontekstualitas al-Qur'an, Kajian Tematik Ayat-ayat Hukum dalam alQur'an. Cet. III. (Jakarta: Penamadani, 2005.

Zahrah, Muhammad Abu. Ushul Fiqh. Kairo, Dar al-Fikr al-Araaby, 1958.

Zahrah, Muhammad Abu. Ushul Fiqh. Terjemahan Saefullah Ma'shum ddk. Cet. II. Jakarta: PT. Pustaka Firdaus, 1994. 